\title{
Faith-Based Actors in Şanliurfa, Turkey: Reducing Tensions Between Host Populations and Syrian Refugee Communities
}

\section{Zeynep Şahin Mencütek}

\begin{abstract}
Preventing possible tensions between refugees and the host population has become a policy priority for countries hosting large numbers of refugees. In addition to local, national and international humanitarian actors, faith-based actors from both host and refugee communities attempt to prevent any tension, as it may disrupt public order, migrant integration and social cohesion. However, little is known about the mechanisms and strategies used by refugee-led faith-based actors to take a role in reducing tensions between host-community and refugees. This article examines refugee-organised faith-based actors' capabilities, limits and interactions with host city actors in conflict prevention, by drawing from the case of Şanlıurfa, a Turkish border province which hosts half a million Syrian refugees. Based on ethnographic field research, including interviews and participant observation, as well as the analysis of local media outlets, the paper focuses on the engagements of faith-based actors of Syrian refugee community with the local actors of Şanllurfa. Findings illustrate that faith-based actors are able to prevent escalation of social tensions in early stages when they coordinate and cooperate with local political and humanitarian actors. However, their effectiveness in preventing tensions in later stages remains limited and does not fully eliminate the risk of violence, as such tensions are often underpinned by socio-economic factors. Finally, the case shows that faith-based actors' engagement in refugee-host community relations lead to small but significant contributions that come with risks and challenges.
\end{abstract}




\section{Introduction}

Preventing conflict between refugees and host populations is a pressing policy issue in refugee host countries. Each country witnesses complex interactions between actors using varying strategies and resource capabilities to prevent potential conflict. Host state authorities often implement immediate security measures, while local associations and international non-governmental organisations focus on conflict prevention by adopting small-scale social cohesion projects. Faith-based actors from both host and refugee communities are often also involved in conflict prevention.

The United Nations High Commissioner for Refugees (UNHCR) underlines the importance of partnering with faith-based actors - grouped under three types: faith-based organisations, local faith communities and faith leaders. ${ }^{1}$ Faith-based organisations encompass religious and religion-based organisations or networks, communities belonging to a place of religious worship, specialized religious institutions and religious social service agencies, and registered or unregistered non-profit institutions that have a religious character or mission." ${ }^{2}$ Local faith communities are not organised, rather, they are composed of people who share common religious beliefs and values. Local faith communities mobilize and provide support through their membership and faith networks, often voluntarily, considering it a tenet of their faith to do so in humanitarian emergencies. Though, they do not necessarily act by referring to humanitarian principles. Faith leaders, drawing power from trust and moral authority over members of their local faith community, are those "who play influential roles within their faith communities and the broader local community." They shape public opinion in the broader community. ${ }^{3}$ It is worth noting that "a refugee who regularly attends a church or mosque does not necessarily identify themselves with the label 'local faith community member,' as current humanitarian language tends to capture them."

When responding to humanitarian crises and providing relief and assistance to vulnerable people, ${ }^{5}$ faith-based actors sometimes have advantages over secular organisations. These derive from their ability to respond faster through social networks, mobilisation experience and financial capital. Further, their religious affiliations may create affinity with the affected communities.

However, there are also concerns about the neutrality and objectivity of these actors as well as donor expectations, as they often fail to comply with international humanitarian standards. ${ }^{6}$ For example, Gulf-funded humanitarian organisations providing aid to Syrian refugees in Lebanon often make " ad hoc deliveries with few administrative procedures and

\footnotetext{
${ }^{1}$ UNHCR, "Partnership note: On Faith-based organisations, Local Faith Communities, and Faith Leaders," Website, UNHCR, 2014, available at: https://www.unhcr.org/539ef28b9.pdf [last accessed 20 April 2018].

${ }^{2}$ Ibid.

${ }^{3}$ Ibid.

${ }^{4}$ Estella Carpi, "Does Faith-Based Provision Always Localise Aid?," Website, Refugee Hosts, 22 January 2018, available at: https://refugeehosts.org/2018/01/22/does-faith-based-aid-provision-always-localise-aid/ [last accessed 25 April 2019].

${ }^{5}$ For discussions about faith and humanitarianism see: Elizabeth Ferris, "Faith and humanitarianism: It's complicated," Journal of Refugee Studies, 2011, Vol. 24 (3), pp.606-625.

${ }^{6}$ See: Elena Fiddian-Qasmiyeh, "The pragmatics of performance: Putting 'faith' in aid in the Sahrawi refugee camps," Journal of Refugee Studies, 2011 3, Vol 24 (3), pp. 533-547; Kathryn Kraft and Jonathan D. Smith, "Between international donors and local faith communities: Intermediaries in humanitarian assistance to Syrian refugees in Jordan and Lebanon,” Disasters, 2019, Vol 43 (1), pp. 24-45.
} 
lack of transparency." Despite this, acknowledging that their advantages outweigh their disadvantages, the UNHCR cooperates with some faith-based actors in forced migration responses, particularly in the global South.

Faith-based actors occupy a range of roles dealing with population displacement, mainly centred around provision of basic needs and protection. These actors operate with diverse motives, donors and actor networks. Faith-based actors can also originate from within refugee communities that self-organise after displacement. ${ }^{9}$ Self-organised faith-based refugee groups share similar characteristics with other faith-based humanitarian actors, although they may have less resources and capacities. In refugee protection, faith-based actors present some benefits, such as providing shelter in places of worship, assisting individual vulnerable cases, and ensuring access to healthcare and employment through their networks, and even accompanying detainees. ${ }^{10}$

Moreover, these actors engage in community outreach and advocacy. They conduct activities supporting social cohesion between refugees and host communities. They contribute to mediating tension between refugees - or internally displaced persons - and host communities through reconciliation and peace-building activities that combat xenophobia and discrimination. ${ }^{11}$ Due to their capacity to promote social cohesion, host countries, national actors and international non-governmental organisations (INGOs) may work with faith-based actors.

However, the implications of cooperation with faith-based actors have not been adequately addressed in existing literature, providing only incomplete analysis on faith-based actor's roles in reducing tension. This paper addresses this gap by exploring recent examples of faith-based actors involved in conflict prevention. The focus of the study is Şanlıurfa, a Turkish border province which hosts almost half a million of Turkey's current total of 3.6 million Syrian refugees. ${ }^{12}$ This paper explores the mechanisms and strategies used by faith-based actors to reduce tensions in Şanlıurfa, with reference also to Gaziantep. Further,

\footnotetext{
${ }^{7}$ Susanne Schmelter, "Gulf States' Humanitarian Assistance for Syrian Refugees in Lebanon," Civil Society Knowledge Center, 2019, p.15, available at: https://civilsociety-centre.org/paper/gulf-states $\%$ E2\%80\%99-humanitarian-assistance-syrian-refugees-lebanon. [last accessed 15 May 2019].

${ }^{8}$ UNHCR, op.cit., 2014.

${ }^{9}$ For discussions about faith-based humanitarianism in the migration situations. See: Elena Fiddian-Qasmiyeh (ed) "Special issue: Faith-based humanitarianism in contexts of forced displacement," Journal of Refugee Studies, 2011, Vol. 24 (3), pp. 429-439.

${ }^{10}$ For specific examples where faith-based actors provide services to refugees see: Jessica Eby, Erika Iverson, Jenifer Smyers, and Erol Kekic, "The faith community's role in refugee resettlement in the United States," Journal of Refugee Studies, 2011, Vol 24 (3), pp.586-605; Alexander Horstmann, "Ethical dilemmas and identifications of faith-based humanitarian organisations in the Karen refugee crisis," Journal of Refugee Studies, 2011, Vol 24 (3), pp. 513-532; Nkwachukwu Orji, "Faith-based aid to people affected by conflict in Jos, Nigeria: An analysis of the role of Christian and Muslim organisations," Journal of Refugee Studies, 2011, Vol 24 (3), pp. 473-492; Victoria Palmer, "Analysing cultural proximity: Islamic relief worldwide and Rohingya refugees in Bangladesh,” Development in Practice, 2011,Vol 21 (1), pp. 96-108.

${ }^{11}$ UNHCR, op.cit., 2014.

${ }^{12}$ Republic of Turkey Ministry of Interior, "Yıllara Göre Geçici Koruma Kapsamındaki Suriyeliler," Republic of Turkey Ministry of Interior, 18 April 2019, available at: http://www.goc.gov.tr/icerik3/gecici-koruma $363 \quad 378$ 4713. [Last accessed 29 April 2019].
} 
this paper focuses on faith-based actors' interactions with host city actors and assesses the limits of refugee-organised faith-based organisations' capacities.

The research uses qualitative research methods, consisting of 45 semi-structured interviews conducted throughout 2018 with Syrian refugees, provincial Turkish authorities, and representatives from both international and national humanitarian organisations operating in Şanlıurfa. ${ }^{13}$ Additionally, field observations, informal conversations with host community members, researchers and native volunteers serving the refugee community, as well as discourse analysis of local and national news helped to inform this paper.

The paper argues that faith-based actors are able to prevent escalation of social tensions in early stages, when they coordinate and cooperate with local political and humanitarian actors. However, their effectiveness in preventing tensions in later stages remains limited and does not fully eliminate the risk of violence, as these tensions are often underpinned by socio-economic factors.

\section{Şanlıurfa: from Quiet Host to a Tense Community}

Since 2011, Şanluurfa, a Turkish province bordering Syria, has become a transit and settlement location for Syrian refugees. At the time of writing (April 2019), Şanlıurfa hosted Turkey's second largest Syrian population at $451,434-22 \%$ of the province's population of $2,035,0893 .{ }^{14}$ Şanluurfa is also one of the ten poorest provinces in Turkey, where average family income is approximately half of the Turkish average. ${ }^{15}$ The province has limited job opportunities, is largely un-industrialised and relies on an agricultural economy. Seasonal agricultural jobs are the primary economic activity of many locals. Many rely on secondary income from construction, service sectors, state social security, and NGOs. The geographic proximity, ethnic and social dynamics of Şanlıurfa are significant factors in why nearly half a million Syrian refugees remain in the province.

Şanlıurfa occupies $250 \mathrm{~km}$ of Turkey's $911 \mathrm{~km}$ Syrian border and many Turkish citizens live within $100 \mathrm{~km}$ of the border. The provincial capital is $55 \mathrm{~km}$ away from the border and there are official border crossings in three different towns, namely Akcakale, Mursitpinar, and Ceylanpinar. These remained relatively open to Syrians until 2014, with intermittent closures following Turkish security concerns. Turks and Syrians in this area are also culturally, ethnically and linguistically close. Half of Şanlıurfa's Turkish population speak Arabic and

\footnotetext{
${ }^{13}$ Field research for this paper was funded by RESPOND: Multilevel Governance of Mass Migration in Europe and Beyond Project- Horizon2020 (\#770564), European Commission. This paper was written by the author during her fellowship at the Kate Hamburger Kolleg/Centre for Global Cooperation Research, University of Duisburg-Essen Germany (03/2019-02/2020). All opinions expressed are the responsibility of the author. ${ }^{14}$ Republic of Turkey Ministry of Interior, "Gecici Koruma," Republic of Turkey Ministry of Interior, 11 April 2019, available at: http://www.goc.gov.tr/icerik6/gecici-koruma 3633784713 icerik. [Last accessed 20 April 2019]

${ }^{15}$ Türkiye Istatistik Kurumu (TUIK), “Gelir ve Yaşam Koşulları Araştırması Bölgesel Sonuçları,” 27 September 2016, Turkish Statistical Institute file:///C:/Users/hp/Downloads/Gelir_ve_Ya\%C5\%9Fam_Ko $\%$ C5\% $\%$ Fullar\%C4\%B1_Ara\%C5\%9Ft_27.09.2016 .pdf. [Last accessed 20 April 2019].
} 
Kurdish, in addition to Turkish, and there are many kinship ties between Syrians and Turks in the area.

The Turkey-Syria border can be defined as a "geopolitical" and "national border" in William Walter's categorisation. This means that it is a border marking both the limit of state control over territory, and the limit of the state's ability to homogenise national identity. Despite efforts since the early $2 \mathrm{O}^{\text {th }}$ century, ${ }^{17}$ the borderlands in the southeast of Turkey and northern Syria have not been fully homogenised with the rest of their respective nation states due to the continuation of cross-border cultures after the demarcation of national borders. Cross-border social and economic relations have continued in different forms from marriages to trade and smuggling, and even daily visits as border regulations have allowed.

In the words of sociologist Mahmut Kaya, "although a border is a physical fixed durable entity," ${ }^{18}$ this border has never been accepted in the sociological imagination of local people who consistently say that "these political borders were artificially and forcibly drawn by nation-states on the territories of the Ottoman Empire, divided families and tribes, while the same border communities continued their relations in various forms." ${ }^{19}$ These ethnic, linguistic, religious, kinship, and tribal ties between locals and Syrians initially provided welcoming attitudes to refugee arrivals. Community leaders drew on social capital to self-initiate mediation when problems arose.

\section{Tensions Emerge Between Host Communities and Syrian Refugees}

Şanllurfa is one of the most highly concentrated Syrian-hosting provinces after Istanbul. ${ }^{20}$ According to media reports, fieldwork observations and interviews with key informants, the overall experience has been relatively peaceful between Syrian refugees and locals compared to neighbouring province, Gaziantep - without major violent episodes until 2018. It should be noted that, in general, Turkey has witnessed only occasional outbreaks of tension with Syrians, with few incidents of heavy violence. ${ }^{21}$ In May 2015, a protest marching under

\footnotetext{
${ }^{16}$ Current borders of Turkey were drawn by Treaty of Lausanne in 1923 after Turkey's War of Independence. During the Ottoman Empire, borders were more permeable, there were strong kinship, tribal, religious, ethnic ties. Due to Turkey's national security related concerns and territorial disputes with neighbouring countries ( e.g. Syria over Hatay). The southeast borders remained important and subject to securitisation until the 2000s.

${ }^{17}$ Hatice Pinar Senoguz, "Border Contestations, Syrian Refugees and Violence in the Southeastern Margins of Turkey," Movements. Journal for Critical Migration and Border Regime Studies, 2017, Vol. 3 (2), pp.165-178; William Walters, "Mapping Schengenland: Denaturalizing the Border," Environment and Planning D: Society and Space, 2002, Vol. 20 (5), pp.561-580.

18 Turkey-Syria border formation went through different stages, including placing border markers (1923), launching wires and land mines (1950s-1980s), removing physical barriers at certain parts of the Turkish-Syrian border (2008), mutually lifting visa requirements (2009), and erecting a security wall (2016-2018). See: Aras Ramazan, "The Wall: (dis)continuities of the state making practices on the Turkish-Syrian border," The American Anthropological Association Annual Meeting, 29 November - 3 December 2017, Washington DC., USA.

${ }^{19}$ Mahmut Kaya Speech, RESPOND Project 1st Roundtable Meeting, 17 December 2018, Istanbul.

${ }^{20}$ Republic of Turkey Ministry of Interior, "Gecici Koruma," Republic of Turkey Ministry of Interior, April 2019, available at: http://www.goc.gov.tr/icerik6/gecici-koruma 3633784713 icerik. [Last accessed 20 April 2019]

${ }^{21}$ Al-Araby, “Turkey jails two for life over murder and rape of pregnant Syrian refugee," Website, Al-Araby, 17 January 2018, available at: https://www.alaraby.co.uk/english/news/2018/1/17/turkey-jails-two-for-life-over-syrian-refugee-murders [Last accessed 20 April 2018].
} 
the banner of "We do not want Syrians" was planned by locals in Şanluurfa. However, the provincial government did not allow it, and even arrested those disseminating similar slogans through social media. ${ }^{22}$ Despite government warnings, some locals still went to protest. However, many were immediately detained by security forces. ${ }^{23}$

Tension escalated into violence between locals and Syrian refugees in October 2018. The trigger was the murder of two Turkish brothers, and the wounding of another two, by Syrians. ${ }^{24}$ Social media news of the event spread rapidly and hundreds of locals (Urfahlar) gathered in front of the municipal town hall. The angry crowd mobilized to terrify Syrians and attacked some, chanting "We do not want Syrians." Many Syrian stores were stoned and heavily damaged. ${ }^{25}$ Security forces intervened to stop protestors attacking Syrians and arrested eight Syrians allegedly involved in the fighting and the murders, while detaining over 20 Turks who disseminated provocative messages on social media. They also placed extra security measures in neighbourhoods where Syrians lived in large numbers. Calming down the protestors took nearly a week, ${ }^{26}$ and many Syrians were afraid to leave their houses or open their stores for days. ${ }^{27}$

Several months before the incident, during fieldwork, escalating tension was tangible through the anti-Syrian discourse among locals, including the key authorities such as muhtars, ${ }^{28}$ public bureaucrats, and directors of line ministries's provincial branches, e.g. Ministry of Interior, Ministry of Education, Ministry of Labor, Family and Social Policies, and Ministry of Health. In communication with locals, often the first topic on the table was the high number of Syrians in the province and narratives around Syrian "wrongdoings." Anti-Syrian statements included "Syrians are taking our jobs," "They use the public buses freely," "There is no space for us in the public parks, because all are filled by them," and "Syrians do not behave properly as guests."

Some statements were highly gendered such as "Syrian men are shameless, they sit in front of their houses and smoke water pipes," "Syrian women wear a lot of make-up, spend all of their

\footnotetext{
${ }^{22}$ Göbeklitepe Haber, “Suriyelileri Istemiyoruz Provokasyonu Yasakland1," Website, Göbeklitepe Haber, 15 May 2015, available at:

http://www.gobeklitepehaber.com/haber/9883/suriyelileri-istemiyoruz-provakasyonu-yasaklandi.html, [Last accessed 20 April 2018].

${ }^{23}$ Göbeklitepe Haber, “Urfa' da Suriyeli Protestosu Gerginliği,’Website, Göbeklitepe Haber, 17 May 2015, available at: http://www.gobeklitepehaber.com/haber/9909/urfada-suriyeli-prostesi-gerginligi.html [Last accessed 20 April 2018].

${ }^{24}$ The murders happened as a result of fighting between a Turkish and a Syrian family, which began with the fights among children in a neighborhood where mainly poor Syrians and locals live together. Two young sons of Turkish family died. See: Urfahaber,’Urfa'da 2 kişinin ölümüne karışan 8 Suriyeli tutuklandı,” Urfahaber, 30 September 2018, available at:

https://www.urfahaber.com/urfa-da-2-kisinin-olumune-karisan-8-suriyeli-tutuklandi/1892/ [Last accessed 20 April 2018]; Alinteri, “Urfa'da Suriyelilere saldırılar başlad1,”, Alinteri, 29 September 2018, available at: https://gazete.alinteri1.org/urfada-suriyelilere-saldirilar-basladi [last accessed 20 April 2018].

${ }^{25}$ Tuba Cameli, "Vallahi Billahi Suriyeli Değiliz!,"Birartıbir, 3 January 2019, available at: https://www.birartibir.org/goc-ve-multecilik/227-vallahi-billahi-suriyeli-degiliz [Last accessed 20 April 2018]. ${ }^{26}$ Ibid.

${ }^{27}$ Mahmut Bozarslan, "Şanlıurfa' da neler oluyor," Voice of America (Turkish Edition), 30 September 2018, available at: https://www.amerikaninsesi.com/a/sanl\%C4\%B1urfada-neler-oluyor/4593584.html [Last accessed 20 April 2018].

${ }^{28}$ Muhtar means the elected head of a village and neighbourhood.
} 
money on coiffeur and cosmetics, they marry with our local men, often as a second wife." Other negative statements contained prejudices, and discrimination. ${ }^{29}$ I saw a restaurant in the main market with a sign saying "This store is not a Syrian store, it is Urfall" protesting that Syrians opened their own stores on this shopping street. Along with other statements, this signalled that sharing economic resources had become a point of tension between the host and refugee communities.

As Senoğuz notes "reactions among the local population at the border have been shaped and turned into struggles over the definition and meaning of society - over the question of who belongs and who does not. ${ }^{, 30}$ According to the people of Şanlıurfa, Syrians do not belong to the city, thus they should not be too visible in urban space. Syrians' "intense" usage of parks, pavements, public buses and markets made the host community concerned about the perceived changing ownership of the city.

Many interviewed Syrians were aware of increasing anti-Syrian sentiments. They recalled incidents of discrimination and assault experienced in public buses, work places, and neighbourhoods. However, none reported physical violence by locals against Syrians until June 2018. Gradually, anti-Syrian attitudes in the city became more widespread and violent, leading to multiple deaths of Syrians in the city.

As mentioned earlier, the level of communal conflict remained relatively low until $2018{ }^{31}$

\footnotetext{
${ }^{29}$ For a survey results about local's perception of Syrians. See: Ahmet Doğan, Şanlıurfa'daki Yerel Halkın Suriyeli Sı̆̆ınmacılara - Mültecilere Yönelik Algısı, 30 March 2019, available at:

https://www.raporlar.org/urfadaki-yerel-halkin-suriyeli-siginmacilara-yonelik-algisi-ahmet-dogan/. [last accessed 05 February 2019].

${ }^{30}$ Hatice Pinar Senoguz, op.cit., 2017
${ }^{31}$ Reported fighting and lynching attempts shared on the local and national media between Syrians and locals in
which police intervened (chronologically): 1) Fighting between a local and Syrian group in a Syrian store,
galvanised stoning of Syrian houses and stores in the neighborhood on 20 August 2018. See: Urfadasin,
"Şanlıurfa'da Suriyeli ve Türk İki Grup Birbirine Girdi!” Website, Urfadasin, 20 August 2018, available at:
https://www.urfadasin.com/Sanlıurfa-da-suriyeli-ve-turk-iki-grup-birbirine-girdi [last accessed 15 April 2019];
}

2) Quarrel between groups in the city center market on 26 March 2017. See: Şanlıurfa 63 TV, "Şanlıurfa'da Şanlıurfalılar ve Suriyeliler kavga etti," Video, Youtube, 26 March 2016, available at:

https://www.youtube.com/watch? $v=P P p B x F M I R 58$ [last accessed 15 April 2019]; 3) Lynch attempts against Syrian stores in parallel to the rumors about a Syrian man attacked Turkish police, on 5 April 2017. See: Ali Guzel, “Urfa'da Suriyeliler yine hedefte,” Evrensel, 5 April 2017, available at:

https://www.evrensel.net/haber/314771/urfada-suriyeliler-yine-hedefte [last accessed 15 April 2019]; 4) Fighting triggered by children's quarrel on the Street, became large with the participation of reportedly 100 people (beatings, stonings, wounding) on in a public park in Haliliye on 31 May 2017. See: NTV, "Şanlıurfa'da Suriyeliler ile mahalleli arasında kavga," NTV, 31 May 2017, available at: https://www.ntv.com.tr/turkiye/sanliurfada-suriyeliler-ile-mahalleli-arasinda-kavga,7BWO1Yeui0O 4wDOa9xi HQ [last accessed 15 April 2019]; 5) Fighting between local and Syrian family, wounding, on 8 September 2016. See: Yenisafak, "Şanlıurfa' da mahalle karıştı; 3 yaralı - Urfa haberleri," Yenisafak, 8 September 2016, available at: https://www.yenisafak.com/Șanlıurfada-mahalle-karisti-3-yarali---urfa-haberleri-h-2528211 [last accessed 15 April 2019]; 6) Street fighting between locals and Syrian groups in Haliliye, stoning of stores and houses by two groups on 1 August 2014. See: Al Jazeera Turk, "Urfa'da Suriyeli gerginliği," Al Jazeera Turk, 1 August 2014, available at:http://www.aljazeera.com.tr/haber/urfada-suriyeli-gerginligi [last accessed 15 April 2019]; 7) Fighting between locals and Syrians in a local store with the involvement of 20 people, many wounded on 20 October 2013. See: Dogru haber, "Urfa`da halk ile Suriyeli mülteciler kavga etti: 20 yaralı,” Dogru haber, 10 October 2013, available at: https://dogruhaber.com.tr/haber/102110-urfada-halk-ile-suriyeli-multeciler-kavga-etti-20-yarali/ [last accessed 15 April 2019]. 
unlike the neighbouring province of Gaziantep, which hosts less Syrians. It experienced violent riots on August 11, 2014, after the alleged murder of a Turkish landlord by his Syrian tenant. Syrians were lynched and their shops, cars and houses were vandalized by Turkish locals. $^{32}$ Anti-Syrian riots occurred on July 15, 2016 in Ankara's Önder neighbourhood, where more than 40,000 Syrians live, and houses and businesses of Syrians were damaged. ${ }^{33}$

In addition, there are no legal deterrents imposed by state authorities. It is not yet fully understood which actors, factors, and mechanisms played roles in preventing the escalation of violence in Şanlıurfa, before the end of 2018.

\section{Syrian Refugee Organisations and Relations with Local Actors}

Formal and informal organisations established by Syrians have flourished in Şanliurfa since 2012. Although there are no firm numbers about such organisations due to a lack of registration, experts from Şanlıurfa estimate there are between 100 and 150 civil society organisations established by Syrians in the province, almost half of which are faith-based. Legally, only Syrians who have a residence permit are allowed to establish, and become members of, registered associations.

Thus, many organisations do not register because most Syrians are neither holders of Turkish passports nor of residence permits, and some even lack temporary protection status. ${ }^{34}$ The organisations which are legally registered are often established in partnership with Turks and Syrians who are in possession of a passport or who have obtained Turkish citizenship. The founders of these organisations are usually highly educated Syrians with political, economic, and social capital.

Refugee-created organisations carry out several services, and their functions are shaped by Syrians' needs. Their primary service areas include education, vocational training, providing socio-psychological support, and caring notably for orphans and people with disabilities. For example, the Rakkaevi Association accommodated thousands of newly arrived Syrians between 2013 and 2015, while the Yasmin Sham Association supports disabled Syrians. ${ }^{35}$ Some cultural centres such as Nofara Syria Cultural Centre serve as both shelters and platforms for organising panels, seminars, celebrations, conferences, and theatre activities. ${ }^{36}$

In recent years, due to increasing needs and funding conditionality, newly established Syrian organisations focused on employment and integration-related activities. For example, the Usame bin Zeyd Cultural Center - established in 2017 with the financial support of Kuwaiti businessmen $^{37}$ - provides vocational training to Syrians. ${ }^{38}$

\footnotetext{
${ }^{32}$ Hatice Pinar Senoguz, op.cit., 2017.

${ }^{33}$ Feyzi Baban, Suzan Ilcan and Kim Rygiel, "Playing Border Politics with Urban Syrian Refugees. Legal Ambiguities, Insecurities, and Humanitarian Assistance in Turkey," Movements Journal for Critical Migration and Border Regime Studies, 2017, Vol. 3(2), pp. 81-102.

${ }^{34}$ Mahmut Kaya, "Komşuda misafirlik: Suriyeli sı̆̆ınmacılara kurulmuş mülteci derneklerinin perspektifinden Türkiye'de yaşamak,” The Journal of Academic Social Science Studies, 2015, Vol 39, pp. 263-279.

${ }^{35}$ Ibid., p. 269.

${ }^{36}$ Ibid.

${ }^{37}$ The Said PhilanthropyAssociation of Kuwait also opened orphanages for Syrian girls and plans to open a school in addition to its regular food aid deliveries. The Governorate of Şanlıurfa and Provincial National
} 
Organisations and businessmen from the Arab states of the Persian Gulf, particularly those from Qatar and Kuwait also distribute cash and aid in-kind to Syrian refugees through Quranic courses and local faith associations. Funding from Gulf countries is also used to finance educational facilities for Syrians. However, none of the Syrian associations interviewed indicated Gulf countries as their sponsors. In Turkey, as in Lebanon, "these organisations function largely outside the United Nations' response and rely on their own coordination structures," nevertheless they coordinate with some state agencies. ${ }^{39}$

Some Syrian associations mediate between the Turkish state and Syrian communities, helping Syrians access public services such as civil registration, schooling, and making business investments. Beside their philanthropic priorities, some, such as Insan Foundation, organise activities for raising awareness about Syrian rights in Turkey. Local rights-based NGOs often collaborate with international NGOs. ${ }^{40}$ There are also some Syrian NGOs organising cultural activities, religious courses, and publishing in Arabic to maintain refugees' Syrian identity. ${ }^{41}$ Such organisations also serve as community platforms for mediating problems between Syrians, including intra-family problems and divorce cases. ${ }^{42}$ While some are self-funded or receive grants from INGOs, international remittances from Syrians in Europe or Arab Gulf countries also finance such associations and cultural centres.

Some of these actors among the Syrian refugee community are faith-based actors from Syria. Social recognition of religious leaders persists after community disruption. In Şanlıurfa, substantial numbers of Syrian religious figures ${ }^{44}$ run madrasas (schools) - often with orphanages or dormitories - which are mainly attended by Syrians. It is estimated that there are around 20 courses, with no precise figures on participant numbers. Course organisers and religious teachers serve as community leaders and have regular audiences participating in activities. ${ }^{45}$ With regular courses and interaction, they shape public opinion of sections of the Syrian refugee community in Şanlıurfa.

Moreover, these community-based faith leaders often seek to create specialized religious institutions and religious social service agencies. Unlike the associations mentioned above,

\footnotetext{
Education directorate signed a protocol with the association and cooperated with its educational aids. See: The Ministry of Education, “Kuveyt Said Yardım Derneği Şanlıurfa'da okul yapacak,” Website, The Ministry of Education, 9 December 2017, available at: https://Sanlıurfa.meb.gov.tr/www/kuveyt-said-yardim-dernegi-Sanllurfada-okul-yapacak/icerik/1750 [Last accessed 20 April 2019].

${ }^{38}$ Göbeklitepe Haber, “Kuveytlilerden Suriyelilere Kültür Merkezi," Website, Göbeklitepe Haber, 04 April 2017, available at: http://www.gobeklitepehaber.com/haber/14419/kuveytlilerden-suriyelilere-kultur-merkezi.html. [Last accessed 20 April 2019].

${ }^{39}$ Susanne Schmelter, op.cit., 2019.

${ }^{40}$ Interview with the director of Insan Foundation, Şanlıurfa, 18 July 2018.

${ }^{41}$ Interview with the director of Akım Foundation, 17 July 2019.

${ }^{42}$ Interview with the Syrian religious scholar and manager of the religious course for Syrians, Şanliurfa, 19 July 2018.

${ }^{43}$ Mahmut Kaya, op.cit., 2015, p.270.

${ }^{44}$ They are called alim. They do not call them as molla, as they are from Sunni tradition. The concept of molla is attributed to Shia tradition.

${ }^{45}$ Author's interview with the Syrian religious scholar and manager of the religious course of Syrians, Şanlıurfa, 19 July 2018; Author's Interview with a teacher running three religious courses, 19 July 2018, Şanliurfa, Turkey; UNHCR, op.cit., 2014..
} 
they are "unregistered non-profit institutions that have a religious character and mission.," In Şanliurfa, in 2014, a number of Syrian religious scholars created an informal assembly called the "Şanlıurfa Sharia Assembly" (Suriyeli Alimler Birliği). They aimed to solve the problems of Syrian refugees in civil issues such as marriage, divorce, and inheritance, which marked early signs of religious legal pluralism for Syrians in Turkey. This was necessary given that many Syrians lack legal refugee status in Turkey and are unable to apply to Turkish courts for family-related issues. The members of the Assembly also issue fatawa (Islamic rulings) when needed and reconcile conflicting parties.

\section{Relations Between Host Community Actors and Refugee-Created Faith-Based Actors}

In Şanlıurfa, provincial state authorities have taken a flexible approach to the activities of formal and informal faith-based Syrian actors. However, they do not directly cooperate due to concerns about their legality. That is, although Syrian stakeholders often have legal status, their collectives - such as Quranic courses, masjids (praying places) or associations - often remain unregistered with state authorities. Instead, local NGOs which work closely with provincial state authorities build direct relations with Syrian NGOs. Thus, Turkish local NGOs became able to coordinate activities with Syrian faith-based organisations on behalf of state authorities.

For example, national organisations such as the Humanitarian Relief Foundation (IHH) and Insani Yardım Platformu ${ }^{47}$ - an umbrella forum bringing together 183 local NGOs - operate in Şanlıurfa. The same local NGOs are also supported by provincial and municipal governments. In fact, actors in those local NGOs, provincial and municipal governments are often from similar networks. They know each other well and worked together before the Syrian crisis. The forum coordinates the interactions of some formal and informal Syrian organisations with the provincial and municipal governments.

Thus, provincial state authorities collaborate with Syrian religious community leaders via this local forum. They established close relations with Syrian faith-based organisations, using religious solidarity as a point of reference for building on trust networks. Islamic references to migration experiences such as "ensar," (host community) "muhacir," (migrant) and "hicra" (migration) enhance solidarity among Muslims. Their narratives centre around the idea that "any tension is because of provocations aimed at dividing the Muslim community." provocation-focused narrative aims to build conflict prevention mechanisms among locals and Syrians.

The reactions to the anti-Syrian protests of July 2017 typify interactions between faith-based refugee organisations and host community actors with regards to conflict prevention at the provincial level. In that month, anti-Syrian discourse started to be widely disseminated

\footnotetext{
${ }^{46}$ Ibid.

${ }^{47}$ Author interview with the director of Insani Yardım Platformu, Şanliurfa, 25 July 2018.

${ }^{48}$ Cinar'in Sesi, "Suriyeli alimler: hep birlikte sevgi ortaminı olustrumamız gerekiyor," Website, Cinar'in Sesi, 14 July 2017 , available at: http://www.cinarinsesi.com/suriyeli-alimler-hep-birlikte-sevgi-ortamini-olusturmamiz-gerekiyor-126770h.htm.
} [Last accessed 20 April 2019] 
through social media, escalating tensions in the province. It followed a tragic event in which a pregnant Syrian was raped and bludgeoned to death by Turkish attackers in Turkey's north-western Sakarya province. ${ }^{49}$

The province saw the emergence of a grassroots initiative - the self-titled Akiller/Alimler Girişimi (Wise Men Initiative) that comprised mainly local organisations who invited refugee-created faith-based organisations. The Initiative was composed of representatives from the umbrella forum Humanitarian Aid Platform and of Syrian religious scholars and leaders. They organised a workshop called "Civic Prevention Mechanisms Workshop for the People's Peace” to discuss how to prevent rising anti-Syrian sentiments from disrupting social cohesion in the city.

The workshop also included Iraqi and Palestinian migrant associations and religious figures.

${ }^{50}$ Participants in the workshop referred to themes such as ensar, muhacir, and Islamic brotherhoods. Turkish NGO representatives underlined the need for caution against provocateurs who try to "mess up Turkey." The workshop produced a public statement warning Syrians not to disrupt the public order and norms of locals. The statement contained seven points of advice to Syrian refugees living in the city.

\section{Public Statement of the Wise Men Initiative: Advice to Syrian refugees in Şanlıurfa}

1-Develop social relations with local neighbours in a kind manner

2-The most common complaint about Syrians in the city is about Syrians' noisy lifestyle bothering locals in the same building. Be careful about the sensitivities of your neighbours, respect them. You will see that they will reciprocate with respect. The worldwide norm is that guests comply with the rules of the host. We should be grateful to the people of this country, the people of this city and the government which opened their arms to us like ensar in our hardest times. If it is not urgent, please do not go out after 23.00.

3- Do not smoke water-pipe tobacco, play, lay down to relax, listen to music and speak on the phone in high volume in public places such as parks, squares, and streets. Do not laugh loudly and make a mess in your neighbourhood. Do not loiter if there is no need to. Please warn Syrians who do not behave properly.

4- Do not hang around as a sole individual or as a big group of Syrians. Hang around as 2-3 persons. If possible, hang around with your local neighbours. This is important for your security and to have a witness if something happens.

\footnotetext{
${ }^{49}$ Al-Araby, "Turkey jails two for life over murder and rape of pregnant Syrian refugee," Website, Al-Araby, 17 January 2018, available at:

https://www.alaraby.co.uk/english/news/2018/1/17/turkey-jails-two-for-life-over-syrian-refugee-murders [Last accessed 20 April 2018].

${ }^{50}$ Göbeklitepe Haber, “Şanlıurfa'daki stk lardan tedbir çalıştayı,” Website, Göbeklitepe Haber, 7 October 2017, available at: http://www.gobeklitepehaber.com/haber/14752/Sanlıurfali-stklardan-tedbir-calistayi.html [Last accessed 20 April 2018]; Göbeklitepe Haber, "Suriyeli aydınlar uyardı," Website, Göbeklitepe Haber, 7 July 2017, available at: http://www.gobeklitepehaber.com/haber/14745/suriyeli-aydinlar-suriyelileri-uyardi.html, [Last accessed 20 April 2018].

${ }^{51}$ Göbeklitepe Haber, "Şanlıurfa Daki stk lardan tedbir çalıştayı,” op.cit., 2017.
} 
5- Do not respond if someone teases you in provocation. If this person insults you badly, call the 155 police line to ask for help.

6- As provincial security forces informed us, Syrians involved in crime and those who encourage others in crime will be immediately deported in order to protect innocent Syrians.

7- We hope that you will take our warnings into account for the security of the Syrian and Turkish publics. We hope that better days await the peoples of Syria and Turkey and that God will help us as muhacir and Urfa people as ensar. We hope that God will not give

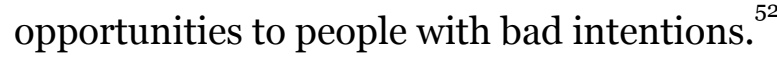

In addition to sharing this statement with the media, representatives from the workshop made house visits in neighbourhoods with large Syrian populations. During these visits, they communicated the aforementioned statement. ${ }^{53}$ Recognising locals' increasing hostility and seeking to avoid further tensions, Syrians seemed to accept these measures. However, it was difficult to assess the exact impact of such statements on the Syrian refugee community. As such, there is not sufficient evidence to argue that this initiative alone reduced the tension. Nevertheless, this statement is worth analysing as an instance in which Syrian and local faith-based actors came together to reduce communal tensions.

Although the initiative seemed promising for also including Syrian faith-based actors in activities aimed at preventing tension, its advice is problematic. This, as it reinforces the hierarchical relationship between locals and Syrians, putting the Syrians in an inferior position. It is based on the premise of the "guest" status of Syrians vis-à-vis the "host" status of local people. The recommendations are problematic for rights-based approaches to Syrian refugees as they imply limiting Syrians' freedom and basic rights. Most of the advice urges Syrians to maintain a low profile and avoid disrupting the lifestyle of locals. Additionally, warnings about deportation feed into a constantly looming threat. Moreover, the advice of calling the police if a Syrian is insulted seems unrealistic, considering that Syrians suffer mistreatment from security forces and that some lack legal documents. The last point, inferring ensar and muhacir, has a strong religious connotation and reproduces Turkish state discourse about refugee governance.

Despite its highly controversial content, the implementation of this initiative through collaboration between local and refugee faith-based actors makes it a significant tool for conflict prevention. As such, it was an underdeveloped conflict prevention mechanism in border provinces hosting large numbers of Syrians like Şanlıurfa. Furthermore, it was a promising example of collaboration between Syrian and local associations, as well as indirect cooperation with state authorities. These characteristics gave it potential for increasing Syrian participation in refugee governance at the local level. However, it should be noted that in this particular instance, "participation" in reality came down do "compliance" with the "other's" terms.

After a year and half, tensions in the province worsened and became more violent. State authorities then bypassed faith-based Syrian actors, which kept a low-profile. The response to

\footnotetext{
${ }^{52}$ Göbeklitepe Haber, "Suriyeli aydınlar uyardı,” op.cit., 2017.

${ }^{53}$ Interview by the author with a local informant who was involved in the workshop and house visits (phone interview), 5 April 2019.
} 
a second incident is helpful in better understanding the interactions between refugee faith-based organisations and host province authorities.

In October 2018, Şanlıurfa saw the murder of two Turkish citizens by Syrians, sparking long-running protests and lynchings that targeted all Syrians living in the city. Provincial state authorities took a strict stance against all forms of violence. The provincial government made announcements to calm the public by attributing the escalation to acts by isolated provocateurs. This narrative of provocation appeased parties who feared that the escalation would reach uncontrollable levels. Moreover, such announcements aimed to demonstrate that the provincial government had taken decisive action. It stated that "eight Syrians involved in criminal activities were under judicial investigation, and around 639 Syrians were deported due to criminal ties. ${ }^{, 54}$ Nevertheless, many locals did not believe such explanations, feeling they were designed to threaten Syrians and appease locals. ${ }^{55}$

Unlike the 2017 incidents, provincial authorities did not seek collaboration with "Wise Men Initiative", despite its recent establishment to enhance collaboration. Rather, they specifically targeted local tribal actors for cooperation because of the context that triggered the tensions. The family of the murdered sons belonged to a large Arab tribe in the city. Thus, there was a risk that the members of the tribe would become involved in fighting and escalate tensions. The governor talked to leaders of the tribe about calming down and not seeking revenge. To assist, tribal leaders made a public announcement noting that "security forces took all necessary measures. We invite people of our city to calm down. We announce that we are with our state and we will not take part in any provocative events against Syrians. ${ }^{, 56}$ This announcement implied that these leaders supported the measures taken by the governorate and security forces and that they would discourage their communities from becoming involved in protests and violence.

Syrian community and faith leaders came together with the governor in consultations. The governor warned Syrians to respect the lifestyle of locals, specifically by avoiding noise at night in their neighbourhoods and public places. Syrian community leaders agreed that the measures were appropriate. They also expressed their sorrow at the murders. Recognising their limitations, they stated that "it is impossible for them to access all Syrians in the city, nevertheless they would do whatever they could do to prevent further escalation." ${ }^{57}$ They again expressed gratitude to locals, their support of the Turkish state, and to help assist implementation.

\footnotetext{
${ }^{54}$ Mahmut Bozarslan, "Şanlıurfa'da neler oluyor,” Website, Voice of America (Turkish Edition), 30 September 2018, Available at: https://www.amerikaninsesi.com/a/sanl\%C4\%B1urfada-neler-oluyor/4593584.html [Last accessed 20 April 2018].

55 Tuba Cameli, op.cit., 2019.

${ }^{56}$ Urfahaber, "Urfa'da 2 kişinin ölümüne karışan 8 Suriyeli tutukland1, Urfahaber, 30 September 2018, available at: https://www.urfahaber.com/urfa-da-2-kisinin-olumune-karisan-8-suriyeli-tutuklandi/1892/ [Last accessed 20 April 2018].

${ }^{57}$ Haberler, "Şanlıurfa valisi Suriyeli kanaat önderleriyle görüştü," Haberler, 1 October 2018, available at: https://www.haberler.com/Șanlıurfa-valisi-suriyeli-kanaat-onderleriyle-11285480-haberi/[Last accessed 20 April 2018].

${ }^{58}$ Haberturk, "Suriyeli kanaat önderleriyle yapılan toplantıda sağduyu mesajı verildi," Haberturk, 1 October 2018, available at:
} 
As in Gaziantep, community perceptions are not static. They can be "quickly upended by nationalist violence and trans-border ethnic ties." across the border, Şanlıurfa has seen major violence at least twice. Although local non-state authorities carried out preventive roles, it was again the state, represented by the provincial government and security forces, that exercised the largest influence in stability and assimilation of Syrian refugees into the host community. It did so by supporting a framework of compliance with host community norms.

Though provincial authorities seek stability and the compliance of the Syrian refugee community with the terms of the local population, I was told by a state officer directing a Youth Center in the province that state authorities tacitly allowed protestors to terrify Syrian refugees for several days without intervening fully. The goal was to "teach" Syrians their limits and that the city belongs to locals. Şanluurfa, like other cities, saw the rioters occasionally set the limits of spatial control over the refugees. Additionally, "emergency responses to the anti-Syrian riot reinforced 'national' boundaries between locals and refugees." It is inevitable that these boundaries also set limits for Syrian faith-based actors.

According to local experts, sharing economic resources and opportunities was a major cause of violent incidents between Syrians and Turks. ${ }^{61}$ Faith-based actors have far less influence over this factor. In 2018, Turkey experienced a currency and debt crisis that led to the closure of many companies, including small- and medium-sized businesses. The crisis saw the price of imported items and some foods rise along with higher unemployment. In Şanliurfa where economic development is relatively low and unemployment was already high - the crisis hit strongly. Increased food prices and unemployment negatively influenced the majority of the population, who already lived under the poverty line. Şanliurfa shopkeepers had to close their shops due to accumulating debts worsened by the currency collapse. ${ }^{62}$ Within this environment, refugees' high visibility, increasing businesses ownership and labour market participation made them an easy scapegoat.

Analysing the two episodes illustrates how faith-based actors, despite their good intentions, can implicitly serve the Turkish state priority of controlling Syrians' presence through a narrative of social cohesion-social and harmony. The participation of these actors in the provincial meetings cannot be taken as evidence of substantive representation of Syrian community. Rather, it is an act of token inclusion of them to local affairs because they are mainly expected compliance, but not mutual cooperation.

https://www.haberturk.com/sanliurfa-haberleri/63702643-suriyeli-kanaat-onderleriyle-yapilan-toplantida-sagduy u-mesaji-verildi [Last accessed 20 April 2018].

\footnotetext{
${ }^{59}$ Hatice Pinar Senoguz, op.cit., 2017, p.165.

${ }^{60}$ Ibid., p. 170

${ }^{61}$ I would like to thank Dr. Mahmut Kaya for directing my attention to this dimension with his feedback.

${ }^{62}$ Urfanatik, "Bahçelievler'de esnaf dertl," Urfanatik, 18 January 2017, available at: http://www.urfanatik.com/yerel/bahcelievler-de-esnaf-dertli-h59216.html, [Last accessed 20 April 2019]; Urfahaber, "Ekonomik krizin alasını yaşıyoruz," Urfahaber, 19 December 2018, available at: https://www.urfahaber.com/ekonomik-krizin-alasini-yasiyoruz/2669/.[Last accessed 20 April 2019].
} 


\section{Conclusion}

The 2018 incident made it clear that the once welcoming attitudes and narratives of Şanluurfa locals are no longer valid and that the refugees' presence had been challenged, or even criminalized. A local researcher studying Urban Sociology noted that "Even if the war ends in Syria, a socio-economic war will continue in Turkey." ${ }^{, 3}$ He adds that "right now Syrians are afraid, but the anger of locals is not over." worsen already-poor local perceptions of Syrians. Moreover, scarce economic resources mean that the economy will remain a potential factor influencing communal tension. Such incidents and responses show that Syrian refugees face tenuous insecurity in all Turkish urban centres regardless of initially welcoming approaches. ${ }^{65}$

Despite promising initial efforts, including Syrian faith-based actors in the context of economic crisis and escalating communal tensions, their role was limited. Furthermore, their efforts, intentionally or not, seemed to rather comply with the Turkish state's efforts to control Syrian presence, under the guise of "social cohesion." The precarious position of Syrian refugees in Turkey is furthered by their temporary protection status. As such, Syrian refugees in Turkey appear to have gradually lost their ability to claim some rights, and remain objects of humanitarian assistance and other means of civil assistance from national actors. Until now, faith-based actors seem unable to eliminate inequalities and limited access to rights and freedoms for Syrians.

In light of this case study, further research is necessary to investigate ways in which faith-based actors attempt to prevent violence between refugees and host communities in countries hosting large refugee populations. It is crucial to explore mechanisms for tension reduction, peace-building activities, and advocacy combating xenophobia and discrimination. It is also important to understand their coordination, cooperation and competition with other local actors in the refugee protection and integration fields. While faith-based actors form an important part of the context "involving local and religious actors should become neither a quick recipe for success nor a standardized strategy of action that separates out the local from the international, the religious from the secular."66

\section{Bibliography}

Alinteri, "Urfa'da Suriyelilere saldırılar başladı," Website, Alinteri, 29 September 2018, available at: https://gazete.alinteri1.org/urfada-suriyelilere-saldirilar-basladi, last accessed 20 April 2018].

Al-Araby, "Turkey jails two for life over murder and rape of pregnant Syrian refugee," Website, Al-Araby, 17 January 2018, available at: https://www.alaraby.co.uk/english/news/2018/1/17/turkey-jails-two-for-life-over-syrian-ref ugee-murders [last accessed 20 April 2018].

\footnotetext{
${ }^{63}$ Tuba Cameli, op.cit., 2019.

${ }^{64}$ Ibid.

${ }^{65}$ Feyzi Baban, Suzan Ilcan and Kim Rygiel, op.cit., 2017, p. 81.

${ }^{66}$ Estella Carpi, op.cit., 2018.
} 
Aras Ramazan,"The Wall: (dis)continuities of the state making practices on the Turkish-Syrian border," The American Anthropological Association, Annual Meeting, 29 November - December 3, 2017, Washington DC., USA.

Feyzi Baban, Suzan Ilcan and Kim Rygiel, "Playing Border Politics with Urban Syrian Refugees. Legal Ambiguities, Insecurities, and Humanitarian Assistance in Turkey,", Movements Journal for Critical Migration and Border Regime Studies, 2017, Vol. 3(2), p. 81-102.

Mahmut Bozarslan, “Şanluurfa'da neler oluyor,"Website, Voice of America (Turkish Edition), 30 September $2018 . \quad$ Available https://www.amerikaninsesi.com/a/sanl\%C4\%B1urfada-neler-oluyor/4593584.html_[last accessed 20 April 2018].

Estella Carpi, "Does Faith-Based Provision Always Localise Aid?,"Website, Refugee Hosts, 22 January 2018, available at: https://refugeehosts.org/2018/01/22/does-faith-based-aid-provision-always-localise-aid/ [last accessed 25 April 2019].

Tuba Cameli, "Vallahi Billahi Suriyeli Değiliz!"Website, birartıbir, o3 January 2019, https://www.birartibir.org/goc-ve-multecilik/227-vallahi-billahi-suriyeli-degiliz, , [last accessed 20 April 2018].

Cinar'in Sesi, "Suriyeli alimler: hep birlikte sevgi ortaminı olustrumamı gerekiyor," Website, Cinar'in Sesi, 14 July 2017, available at: http://www.cinarinsesi.com/suriyeli-alimler-hep-birlikte-sevgi-ortamini-olusturmamiz-gere kiyor-12677oh.htm. [last accessed 20 April 2019]

Ahmet Doğan, "Şanlıurfa'daki Yerel Halkın Suriyeli Sı̆̆ınmacılara - Mültecilere Yönelik Algısı," April 2019. Available at: https://www.researchgate.net/publication/332448161_Sanliurfa'daki_Yerel_Halkin_Suriyeli Siginmacilara_- Multecilere_Yonelik_Algisi [last accessed 12 April 2019].

Dogru haber, "Urfa `da halk ile Suriyeli mülteciler kavga etti: 20 yarall," Website, Dogru haber, 10 October 2013, available at: https://dogruhaber.com.tr/haber/102110-urfada-halk-ile-suriyeli-multeciler-kavga-etti-20-y arali/ [last accessed 20 April 2019]

Jessica Eby, Erika Iverson, Jenifer Smyers, and Erol Kekic, "The faith community's role in refugee resettlement in the United States,” Journal of Refugee Studies, 2011, Vol 24 (3), p.586-605.

Elizabeth Ferris, "Faith and humanitarianism: It's complicated," Journal of Refugee Studies, 2011, Vol 24 (3), p.606-625.

Elena Fiddian-Qasmiyeh, "The pragmatics of performance: Putting 'faith' in aid in the Sahrawi refugee camps,” Journal of Refugee Studies, 2011, Vol 24 (3), p. 533-547.

Ali Guzel, “Urfa'da Suriyeliler yine hedefte,” Website, Evrensel, 5 April 2017, available at: https://www.evrensel.net/haber/314771/urfada-suriyeliler-yine-hedefte [last accessed 20 April 2019]. 
Göbeklitepe Haber, “Kuveytlilerden Suriyelilere Kültür Merkezi,” Website, Göbeklitepe Haber, 04 April 2017, available at: http://www.gobeklitepehaber.com/haber/14419/kuveytlilerden-suriyelilere-kultur-merkezi. html.

Göbeklitepe Haber, "Şanlıurfadaki stk'lardan tedbir çalıştayı," Website, Göbeklitepe Haber, 7 October 2017, available at: http://www.gobeklitepehaber.com/haber/14752/Şanlıurfali-stklardan-tedbir-calistayi.html [last accessed 20 April 2018].

Göbeklitepe Haber, "Suriyeli aydınlar uyardı," Website, Göbeklitepe Haber, 7 July 2017, http://www.gobeklitepehaber.com/haber/14745/suriyeli-aydinlar-suriyelileri-uyardi.html, [last accessed 20 April 2018].

Gobeklitepe Haber, "Suriyelileri Istemiyoruz Provokasyonu Yasaklandı," Website, GöbeklitepeHaber, 15 May 2015, http://www.gobeklitepehaber.com/haber/9883/suriyelileri-istemiyoruz-provakasyonu-yasa klandi.html, [last accessed 20 April 2018].

Gobeklitepe Haber, “Urfa'da Suriyeli Protestosu Gerginliği,”Website, Göbeklitepe Haber, 17 May 2015 , http://www.gobeklitepehaber.com/haber/9909/urfada-suriyeli-prostesi-gerginligi.html; last accessed 20 April 2018].

Haberler, "Şanlıurfa valisi Suriyeli kanaat önderleriyle görüştü," Website, Haberler, 1 October 2018, available at: https://www.haberler.com/Şanlıurfa-valisi-suriyeli-kanaat-onderleriyle-11285480-haberi/ [last accessed 20 April 2018].

Haberturk, "Suriyeli kanaat önderleriyle yapılan toplantıda sağduyu mesajı verildi," Website, Haberturk, 1 October 2018, https://www.haberturk.com/sanliurfa-haberleri/63702643-suriyeli-kanaat-onderleriyle-yapi lan-toplantida-sagduyu-mesaji-verildi [last accessed 20 April 2018].

Alexander Horstmann,"Ethical dilemmas and identifications of faith-based humanitarian organisations in the Karen refugee crisis. Journal of Refugee Studies, 2011, Vol 24 (3), p. $513-532$.

Al Jazeera Turk, "Urfa'da Suriyeli gerginliği," Website, Al Jazeera Turk, 1 August 2014, available at: http://www.aljazeera.com.tr/haber/urfada-suriyeli-gerginligi [last accessed 20 April 2019].

Mahmut Kaya, "Komşuda misafirlik: Suriyeli sı̆̆ınmacılara kurulmuş mülteci derneklerinin perspektifinden Türkiye'de yaşamak," The Journal of Academic Social Science Studies, 2015, Vol 39, p. 263-279.

Kathryn Kraft and Jonathan Smith, "Between international donors and local faith communities: Intermediaries in humanitarian assistance to Syrian refugees in Jordan and Lebanon,"Disasters, 2019, Vol 43(1), p. 24-45.

The Ministry of Education, "Kuveyt Said Yardım Derneği Şanlıurfa'da okul yapacak," Website, The Ministryof Education, 9 December 2017, available at: 
https://Şanlıurfa.meb.gov.tr/www/kuveyt-said-yardim-dernegi-sanliurfaŞanlıurfada-okul-ya pacak/icerik/1750, [last accessed 20 April 2019]

NTV, "Şanlıurfa'da Suriyeliler ile mahalleli arasında kavga," Website, NTV, 31 May 2017, available at: https://www.ntv.com.tr/turkiye/sanliurfada-suriyeliler-ile-mahalleli-arasinda-kavga,7BWO1 YeuioO_4wDOa9xiHQ [last accessed...]

Nkwachukwa Orji, "Faith-based aid to people affected by conflict in Jos, Nigeria: An analysis of the role of Christian and Muslim organisations," Journal of Refugee Studies, 2011, Vol 24 (3), p. 473-492.

Victoria Palmer,“Analysing cultural proximity: Islamic relief worldwide and Rohingya refugees in Bangladesh,” Development in Practice, 2011, Vol 21 (1), p.96-108.

Republic of Turkey Ministry of Interior, "Gecici Koruma," Website, Republic of Turkey Ministry of Interior, 11 April 2019, available at: http://www.goc.gov.tr/icerik6/gecici-koruma_363_378_4713_icerik. [last accessed 20 April 2019].

Republic of Turkey Ministry of Interior, "Ylllara Göre Geçici Koruma Kapsamındaki Suriyeliler," Website, Republic of Turkey Ministry of Interior, 18 April 2019, available at; http://www.goc.gov.tr/icerik3/gecici-koruma_363_378_4713. [Last accessed 29 April 2019]

Şanlıurfa 63 TV, "Şanlıurfa'da Şanlıurfalılar ve Suriyeliler kavga etti,” Video, Youtube, 26 March 2016, available at:https://www.youtube.com/watch?v=PPpBxFMIR58 [last accessed]

Susanne Schmelter, "Gulf States' Humanitarian Assistance for Syrian Refugees in Lebanon," Civil Society Knowledge Center, 2019, available at: https://civilsociety-centre.org/paper/gulf-states\%E2\%80\%99-humanitarian-assistance-s yrian-refugees-lebanon. [last accessed 15 May 2019].

Hatice Pinar Şenoğuz,"Border Contestations, Syrian Refugees and Violence in the Southeastern Margins of Turkey,"in Ilker Ataç, Gerda Heck, Sabine Hess, Zeynep Kasl, Philipp Ratfisch, Cavidan Soykan (eds.), Movements Journal for Critical Migration and Border Regime Studies, 2017, Vol. 3(2), p.165-178.

TÜİK, Gelir ve Yaşam Koşulları Araştırması Bölgesel Sonuçları. 2015, 2016. Available at: http://www.alomaliye.com/2019/09/23/2018-gelir-ve-yasam-kosullari-arastirmasi-bolgesel-so nuclari/ [last accessed 20 April 2019].

UNHCR, "Partnership note: On Faith-based organisations, Local Faith Communities, and Faith Leaders," Website, UNHCR, 2014, available at: https://www.unhcr.org/53gef28bq.pdf [last accessed 20 April 2018].

Urfadasin, “ŞANLIURFA'DA SURIYELI VE TÜRK IKİ GRUP BİRBİRINNE GİRDİ!” Website, Urfadasin, 20 August 2018, available at: https://www.urfadasin.com/Şanlıurfa-da-suriyeli-ve-turk-iki-grup-birbirine-girdi [last accessed].

Urfahaber, "Ekonomik krizin alasını yaşıyoruz," Website, Urfahaber,19 December 2018, https://www.urfahaber.com/ekonomik-krizin-alasini-yasiyoruz/2669/.[last accessed 20 April 2019]. 
Urfahaber,"Urfa'da 2 kişinin ölümüne karışan 8 Suriyeli tutukland,,” Website, Urfahaber, 30 September 2018, available at: https://www.urfahaber.com/urfa-da-2-kisinin-olumune-karisan-8-suriyeli-tutuklandi/1892/ [last accessed 20 April 2018].

Urfanatik, "Bahçelievler'de esnaf dertl," Website, Urfanatik, 18 January 2017, available at: http://www.urfanatik.com/yerel/bahcelievler-de-esnaf-dertli-h59216.html, [last accessed 20 April 2019].

Walters, William. "Mapping Schengenland: Denaturalizing the border," Environment and Planning D: Society and Space, 2002, Vol 20 (5), pp. 561-580.

Yenisafak, "Şanlıurfa'da mahalle karıştı; 3 yaralı - Urfa haberleri," Website, Yenisafak, 8 September 2016, available at: https://www.yenisafak.com/Şanlıurfada-mahalle-karisti-3-yarali---urfa-haberleri-h-2528211 [last accessed] 